\title{
Vertical transmission of human immunodeficiency virus is correlated with the absence of high-affinity/avidity maternal antibodies to the gp120 principal neutralizing domain
}

\author{
Yair Devash*†, Theresa A. Calvelli ${ }^{\ddagger}$, David G. Wood*, Kevin J. Reagan*†, ANd Arye Rubinstein $\ddagger \S$ \\ ${ }^{*}$ E. I. du Pont de Nemours, Medical Products Department, Glasgow, DE 19714-6101; and ${ }^{\ddagger}$ Albert Einstein College of Medicine, Bronx, NY 10461
}

Communicated by Barry R. Bloom, February 7, 1990 (received for review November 29, 1989)

\begin{abstract}
Many, but not all, infants born to mothers infected with the human immunodeficiency virus (HIV) are infected in utero. We have now shown that mothers who have high-affinity/avidity antibodies directed toward the principal neutralizing domain (PND) of gp120 are less likely to transmit HIV to their children. An ELISA that preferentially measures the level of the biologically functioning, high-afiinity/avidity antibodies against PND is described. In a retrospective study of 15 maternal/neonatal serum samples, the assay correctly identified the 4 uninfected and the 11 HIV-infected infants. Other clinical and laboratory parameters such as p24 antigen, phytohemagglutinin mitogenic index, and absolute surface antigen $\mathrm{T4}^{+}$cell counts did not accurately predict HIV fetal transmission. In addition to introducing a promising diagnostic tool, this study provides the in vivo evidence that protective antibodies may prevent infection by HIV.
\end{abstract}

The vast majority of human immunodeficiency virus (HIV)infected children are born to HIV-infected mothers. Substantial evidence exists to support in utero HIV transmission (1, 2). However, not all pregnancies in HIV-infected women result in an infected baby. The rate of maternal/fetal transmission ranges from $25 \%$ to $65 \%$ (2-4). The identification of factors that influence this mode of transmission is critical. Recent studies $(5,6)$ suggested a potential correlation between the prevalence of maternal antibodies against amino acid sequences from the viral gp120 and transmission of HIV from infected mothers to their newborns. Broliden et al. (5) and Rossi et al. (6) showed that $31 \%$ and $46 \%$, respectively, of healthy neonates born to HIV-infected mothers had maternal antibodies directed against the hypervariable region of gp120 derived from the HTLV-III ${ }_{B}$ strain. In contrast, sera of infected neonates generally failed to immunoreact with the same regions. Although the correlations reported were less than optimal, these studies did point to the potential of using site-directed serology to pinpoint critical factor(s) in the maternal immune response.

A region within the external envelope glycoprotein of HIV, between amino acids 296 and 331, has been shown to be critical for neutralization of the virus. This region is known as the principal neutralizing domain (PND; refs. 7-17, I). These amino acid sequences contain a highly conserved amino acid $\beta$-turn tetramer, Gly-Pro-Gly-Arg, with variable sequences on both sides of the $\beta$-turn $(10-14,17)$. Extensive sequence variation within the PND among known isolates exists. However, it was recently shown that the majority of HIV-infected individuals respond immunologically to viruses antigenically related to HTLV-III $\mathrm{MN}_{\mathrm{MN}}$ (15). Direct analysis of PND sequences from field isolates confirmed that the sero-

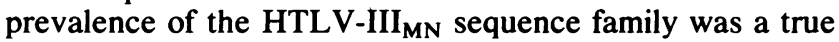
reflection of the infecting strain of $\operatorname{HIV}(18, \mathbb{I})$.

The publication costs of this article were defrayed in part by page charge payment. This article must therefore be hereby marked "advertisement" in accordance with 18 U.S.C. $\$ 1734$ solely to indicate this fact.
Previously reported PND ELISAs $(5,6,15,17)$ and other peptide ELISAs (15) maximized antibody reactivity. Under such conditions, high levels of cross-reaction among divergent PND antigens occurred (15). The present study used an ELISA that preferentially detects high-affinity/avidity antibodies toward the PND. Such antibodies are more reflective of the biologically relevant events.

A retrospective analysis of 15 maternal/neonatal pairs, all with defined clinical outcomes, demonstrated that all 11 infected neonates as well as their mothers had only weak reactivity in the antigen-limited PND ELISA. On the other hand, the sera of 4 uninfected neonates and 3 of 4 of their mothers demonstrated strong reactivity in the ELISA. Other clinical and laboratory parameters [p24 antigen, phytohemagglutinin (PHA) mitogenic index, and absolute $\mathrm{T}^{+}$(surface antigen) cell count] were not predictive of fetal HIV infection.

\section{MATERIALS AND METHODS}

Patients. Eleven of the 15 pregnant women studied at the Albert Einstein College of Medicine were known to be drug abusers. Four women had as their only admitted risk factor heterosexual contact with a male with a known risk factor(s) for AIDS. Three of these male sexual partners were tested and found to be serologically positive for HIV. Blood samples were obtained from most of the women at delivery or within the 3 weeks prior to delivery. For 1 woman who delivered in a different hospital, only one sample from week 18 of pregnancy was available. Cord blood-derived sera and infants' sera obtained up to the age of 4 weeks were also evaluated for antibody levels in the PND ELISA. All newborns were medically evaluated prospectively at the Albert Einstein College of Medicine. Visits were scheduled at ages $1,2,3,6,9$, and 12 months, followed by biannual visits.

Immunological Markers. Peripheral blood mononuclear leukocytes were isolated by sedimentation on Ficoll/ Hypaque $\left(1.077 \mathrm{~g} / \mathrm{cm}^{3}\right)$. In vitro lymphoproliferative responses to phytohemagglutinin (PHA) were determined by incorporation of tritiated thymidine as reported (19).

Quantitation of CD4 and CD8 lymphocytes was carried out by flow cytometric analysis of lysed whole blood dual-stained with anti-T8 conjugated with fluorescein isothiocyanate and anti-T4 conjugated with phycoerythrin (Coulter) using an EPICS-C fluorescence-activated cell sorter (Coulter).

Synthetic Peptides. Peptides were prepared on an Applied Biosystems $430 \mathrm{~A}$ synthesizer by using chemicals and program cycles supplied by the manufacturer. After synthesis,

Abbreviations: HIV, human immunodeficiency virus; PND, principal neutralizing domain; PHA, phytohemagglutinin.

†Present address: Ortho Diagnostics, Raritan, NJ 08869.

§To whom reprint requests should be addressed.

TPutney, S. D., LaRosa, G., Javaherian, K., Emini, E., Bolognesi, D. \& Mathews, T., Fifth International Conference on AIDS, June 4-9, 1989, Montreal, p. 527. 
Table 1. Sequences of synthetic PND assayed

\begin{tabular}{ll}
\hline Strain & $\begin{array}{c}\text { Amino acid } \\
\text { sequence in } \\
\text { single-letter code }\end{array}$ \\
\hline SC & $\begin{array}{c}\text { 307 } \\
\text { RSIHIGPGRAFYA }\end{array}$ \\
MN & KRIHIGPGRAFYT \\
3B(BH10) & IRIQRGPGRAFVT* \\
RF & KSITKGPGRVIYA \\
WMJ1 & RHIHIGPGRAFYT \\
WMJ2 & RSLSIGPGRAFRT \\
WMJ3 & RRIHIGPGRAFYT \\
ARV2 & KSIYIGPGRAFHT ${ }^{\dagger}$ \\
Z3 & QSIRIGPGKVFYA \\
Z6 & QSTPIGLGQALYT \\
NY5 & KGIAIGPGRTLYA \\
SL & TRIHIGPGRAFYT \\
LAVMA & RGIHFGPGALYT \\
LAVEL & QRTPIGLGQSLYT \\
CDC42 & SRVTLGPGRVWT ${ }^{\ddagger}$
\end{tabular}

*Also sequences of 3B(HXB2), H9, LAVIA, BRU, BH8, HXB3, and PV22.

†Also sequence of SF2.

$¥$ Also sequence of CDC4.

peptides were deprotected, cleaved from the supporting resin with trifluoromethanesulfonic acid, and then purified by reverse-phase HPLC. Peptide identities were confirmed by spectral analysis, amino acid composition, and chemical sequencing.

ELISA Methods. PND ELISA. Polystyrene microtiter plates were coated with one of the synthetic peptide PNDs specified in Table 1 . Solutions $(100 \mu \mathrm{l})$ were placed in each well, each solution containing a different PND antigen at 10 $\mu \mathrm{g} / \mathrm{ml}$ in $100 \mathrm{mM} \mathrm{NaHCO}$ (pH 9.6), and plates were incubated overnight, washed, and then blocked. Verifications of PND coating efficiencies were done with each peptide by using labeled peptide derivatives. Human antibodies were diluted 1:20 and allowed to incubate with the peptide-coated wells for $1 \mathrm{hr}$ at $37^{\circ} \mathrm{C}$. Unbound antibodies were removed by washing the wells six times successively with phosphatebuffered saline containing $0.5 \%$ Tween 20 . Bound antibodies were detected by the addition of goat anti-human IgG con- jugated to alkaline phosphatase, followed by a reaction with the substrate pNPP and spectrophotometric measurement of the reaction at $405 \mathrm{~nm}$. The cutoff for sera was defined as the mean absorbance of 10 seronegative samples plus 5 SDs $(P>$ 0.0001).

Antigen-limited ELISA. Polystyrene microtiter plates were coated in parallel with decreasing amounts of synthetic peptide PNDs at concentrations ranging from $1 \mu \mathrm{g} / \mathrm{ml}$ to 0.5 $\mathrm{ng} / \mathrm{ml}$, as described for the PND ELISA. Serum samples were diluted 1:20 and allowed to incubate with the peptidecoated plates for $1 \mathrm{hr}$ at $37^{\circ} \mathrm{C}$, and the amount of bound antibody was quantitated as described for the PND ELISA.

$P N D$ competition assay. PND peptide concentrations that were required to reduce ELISA signals below cutoff were determined by adding the PND peptide at increasing concentrations to each serum. The serum was then tested in the homologous PND ELISA assay (antigen at $10 \mu \mathrm{g} / \mathrm{ml}$ coating concentration).

HIV p24 antigen ELISA. HIV p24 antigen was detected by antigen capture enzyme immunoassay (DuPont or Coulter) using the instructions provided by the manufacturer. Quantities of p24 were determined by using a standard curve of whole viral lysate whose p24 protein concentration was calibrated against affinity-purified p24 antigen as described by the manufacturer.

ENV9 ELISA. The ENV9 ELISA assay (DuPont) measures antibodies directed to the HIV envelope by utilizing a recombinant HIV envelope fragment, env-(474-749). Serum end-point titer (1:4 dilution series) was used as a measure of the level of patient immune response to HIV envelope.

Polymerase Chain Reaction. HIV DNA sequences were detected in peripheral blood lymphocytes by the polymerase chain reaction method as reported (20). Oligonucleotide primers used were SK 38/39 for HIV gag and SK 68/69 for HIV env.

\section{RESULTS}

The retrospective and prospective analyses of all 15 mother/ child pairs identified 4 uninfected and 11 infected children. Table 2 summarizes the essential clinical and laboratory parameters measured for each of the 15 women studied. Clinically, 13 of 15 mothers were classified as asymptomatic,

Table 2. Clinical and immunological status of maternal samples

\begin{tabular}{|c|c|c|c|c|c|}
\hline Patient & $\begin{array}{l}\text { Time of } \\
\text { testing* }\end{array}$ & Clinical status & $\begin{array}{l}\text { In vitro mitogenic } \\
\text { response to } \\
\text { PHA, cpm }\end{array}$ & $\begin{array}{c}\text { Absolute } \mathrm{T}^{+} \\
\text {cell count } \\
\text { per } \mathrm{mm}^{3 \ddagger}\end{array}$ & $\begin{array}{l}\text { p24 antigen, } \\
\mathrm{pg} / \mathrm{ml}\end{array}$ \\
\hline \multicolumn{6}{|c|}{ Mothers of HIV-infected neonates } \\
\hline 1 & 38 & Asymptomatic & 21,383 & 279 & 16.5 \\
\hline 2 & 40 & Asymptomatic & 27,130 & 1380 & Negative \\
\hline 3 & 40 & Mild encephalopathy & 26,161 & 200 & Negative \\
\hline 4 & 40 & Asymptomatic & ND & 946 & $>200$ \\
\hline 5 & 38 & Asymptomatic & 27,540 & 590 & Negative \\
\hline 6 & 18 & Asymptomatic & 43,803 & 432 & Negative \\
\hline 7 & 37 & Asymptomatic (herpes zoster) & 20,134 & 548 & Negative \\
\hline 8 & 40 & Asymptomatic & 37,699 & 162 & 17.4 \\
\hline 9 & 40 & Lymphadenopathy & 70,853 & 252 & Negative \\
\hline 10 & 40 & Asymptomatic & 20,551 & 230 & Negative \\
\hline 11 & 40 & Asymptomatic & 10,776 & 189 & Negative \\
\hline \multicolumn{6}{|c|}{ Mothers of uninfected neonates } \\
\hline 12 & 40 & Asymptomatic & ND & 600 & 101 \\
\hline 13 & 40 & Asymptomatic & 25,915 & 1214 & 18.35 \\
\hline 14 & $39 / 40$ & Asymptomatic & 73,995 & 437 & 38 \\
\hline 15 & $39 / 40$ & Asymptomatic & 11,601 & 286 & ND \\
\hline
\end{tabular}

ND, not determined.

*Weeks of gestation.

$\dagger$ Normal range $=16,533-125,476 \mathrm{cpm}$.

$\ddagger$ Normal range $=464-1364$ cells. 
Table 3. PND antibody distribution of serum from HIV-infected mothers with the HTLV-III $\mathrm{MN}_{\text {family }}$

\begin{tabular}{lccccc}
\hline & \multicolumn{5}{c}{$A$ at $405 \mathrm{~nm}^{*}$} \\
\cline { 2 - 6 } \multicolumn{1}{c}{ Sample } & $\mathrm{MN}$ & $\mathrm{SC}$ & $\mathrm{WMJ} 1$ & WMJ3 & SL \\
\hline Normal controls $^{\dagger}$ & $\mathbf{0 . 0 6} \pm \mathbf{0 . 0 2 4}$ & $\mathbf{0 . 0 5} \pm \mathbf{0 . 0 3}$ & $\mathbf{0 . 0 4 2} \pm 0.0296$ & $\mathbf{0 . 0 4} \pm 0.032$ & $\mathbf{0 . 0 5} \pm 0.028$ \\
Maternal $^{\ddagger}$ & $\mathbf{1 . 6 9} \pm \mathbf{0 . 4 5}$ & $\mathbf{0 . 3 8 6} \pm 0.29$ & $1.184 \pm 0.43$ & $1.48 \pm 0.44$ & $\mathbf{0 . 7 2 6} \pm 0.35$ \\
& $(1.0-2.4)$ & $(0.1-1.2)$ & $(0.5-2.1)$ & $(0.8-2.3)$ & $(0.3-1.4)$ \\
\hline
\end{tabular}

*Average of two independent assays. Absorbance was generated in ELISA at a coating concentration of $10 \mu \mathrm{g} / \mathrm{ml}$.

† Mean $A$ value of 10 seronegative samples $\pm 5 \operatorname{SD}(P<0.0001)$.

$\ddagger$ Mean $A$ value of 15 HIV-infected mothers. $A$ ranges are indicated in parentheses.

with each presenting no notable gestational complications that might predict which fetus might be more likely to have been exposed. Eleven children were classified as infected according to the 1987 criteria of the Centers for Disease Control (CDC; ref. 21). Two of these children have since died. Three infants, all between 7 and 9 months of age, were considered infected because they were persistently serologically positive and had repeatedly detectable serum HIV p24 antigen. One of these children has died from a HIV-related illness. Four children over 15 months of age were considered uninfected based on persistently negative HIV serology [as determined by ELISA and immunoblots (Western blots) (DuPont)], on the absence of detectable serum p24 antigen, on negative HIV DNA polymerase chain reaction, and on the absence of any clinical symptoms suggestive of HIV infection in children as specified by the 1987 Centers for Disease Control criteria (21).

PHA Mitogenic Index and $\mathrm{T4}^{+}$Cell Count. Thirteen of the 15 maternal samples were tested for an in vitro mitogenic response to PHA (Table 2). Nine of 10 tested mothers with infected children showed lymphoblastic responses within normal ranges as did 2 of 3 women with uninfected children. Of the 11 mothers with infected children, 7 (63\%) demonstrated low levels of T4 surface antigen. Two of these women were the only ones in the prospective study who demonstrated clinical signs of HIV disease. Of the women with uninfected children, $50 \%$ ( 2 of 4$)$ showed low T4 ${ }^{+}$cell levels. Taken together, these data did not suggest an ability for either PHA mitogenic responses or absolute $\mathrm{T}^{+}$cell counts to discriminate pediatric HIV infection.

p24 Antigen. The correlation of vertical transmission of HIV-1 with p24 antigenemia was determined. Six of 14 maternal samples showed quantifiable levels of p24 antigen, although none was derived from symptomatic individuals (Table 2). Three of 11 mothers of HIV-infected neonates had p24 antigenemia, whereas 3 of the 4 mothers of uninfected neonates showed p24 antigenemia. These data again suggest that neither the presence nor the quantity of maternal p24 was predictive of HIV vertical transmission.

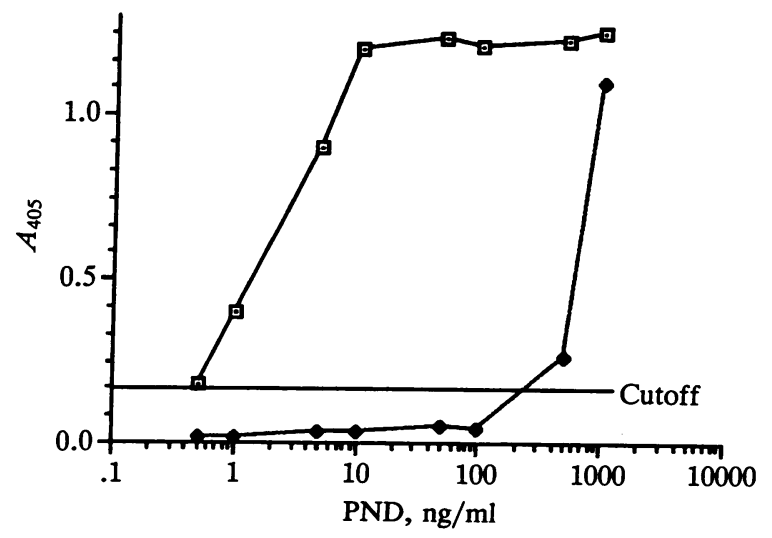

FIG. 1. The immunoreactivity of two human sera with strong PND reactivity $(\square)$ or weak $(\diamond)$ reactivity on the PND-MN antigen-limited ELISA.
Antibody to PND. Antibody distribution. Devash et al. (15) recently provided seroepidemiologic evidence that the HTLV-III $\mathrm{MN}_{\mathrm{N}}$ strain is the predominant HIV infecting strain. To establish that the maternal/neonatal samples that were geographically derived from the New York City area represented the same HIV strain distribution, it was necessary to characterize each serum on a variety of PND synthetic peptides derived from various HIV isolates. ELISA plates were coated at non-antigen-limited concentrations with each of the 15 synthetic peptides (Table 1) representing most of the known HIV-1 PNDs. Preliminary data (not shown) showed that the maternal sera were immunoreactive predominantly

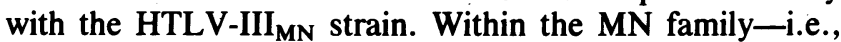
those strains with a backbone of amino acid sequences Ile-His-Ile-Gly-Pro-Gly-Arg-Ala-Phe-Tyr, as in MN, SC, WMJ1, WMJ3, and SL (Table 3)-maternal samples demonstrated their strongest immunoreactivity with the MNassociated PND. The differences in optical density among the various PNDs could not be attributed to different peptide coating efficiencies, since the equivalent amounts of labeled peptides could be shown to coat the wells (data not shown). These data supported the exclusive use of PND derived from

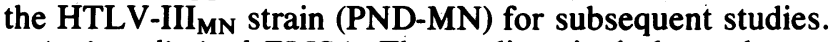

Antigen-limited ELISA. The studies cited above demonstrated substantial cross-reactions among the $\mathrm{MN}$ family of synthetic peptides. Since some of these cross-reactions were likely to be lower affinity interactions, we investigated whether decreasing the antigen concentrations on the solid support was able to eliminate weak immunoreactivities. Human sera at 1:20 serum dilution were tested on decreasing PND-MN concentrations. Representative patterns from two sera are presented in Fig. 1. Both sera were able to generate significant ELISA signal at the PND ELISA coating concentrations of $10 \mu \mathrm{g} / \mathrm{ml}$. However, one serum was immunoreactive with as low as $0.5 \mathrm{ng}$ of PND-MN coating, whereas the other serum was immunoreactive only to $500 \mathrm{ng}$ of PND-MN coating. The antigen-limited ELISA results compared well with the results of PND-MN competition assay. Human sera were preincubated with increasing concentrations of PNDMN peptide, and the amounts required to reduce the ELISA signal below cutoff were determined. As little as $0.1 \mathrm{ng}$ of PND-MN per ml was sufficient to reduce the signal of the human serum that showed a weak immunoreactivity on the antigen-limited ELISA (Table 4, serum 2). In contrast, the

Table 4. Correlation between PND-MN antigen-limited ELISA and competition assays

\begin{tabular}{cccc}
\hline $\begin{array}{c}\text { Serum } \\
\text { sample } \\
\text { no. }\end{array}$ & $\begin{array}{c}\text { Antigen coating } \\
\text { concentration in } \\
\text { antigen-limited } \\
\text { ELISA, }{ }^{*} \mathrm{ng} / \mathrm{ml}\end{array}$ & $\begin{array}{c}\text { PND required } \\
\text { to complete, } \\
\text { ng/ml }\end{array}$ & $\begin{array}{c}\text { ENV9 ELISA } \\
\text { end-point titer }\end{array}$ \\
\hline 1 & 0.5 & 5000 & 100,000 \\
2 & 500 & 0.1 & 100,000 \\
\hline
\end{tabular}

*Lowest antigen coating concentration $(\mathrm{ng} / \mathrm{ml})$ that generated an $A$ signal above cutoff.

†PND-MN concentration $(\mathrm{ng} / \mathrm{ml})$ required to reduce ELISA signal below cutoff.

‡End-point titers (1:4 dilution series) of ENV9 ELISA. 


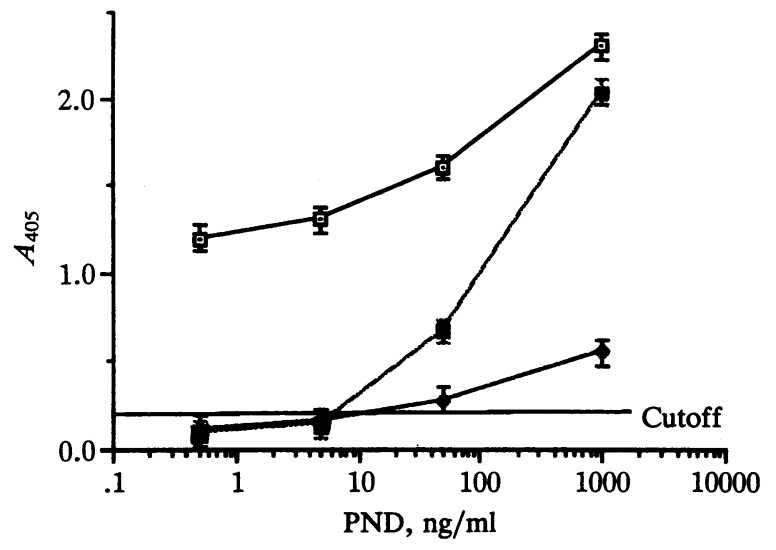

FIG. 2. Immunoreactivity patterns of maternal sera on the antigenlimited ELISA utilizing PND derived from the HTLV-III MN $_{\text {strain. }}$ Three patterns of immunoreactivity were noted $(P<0.0001)$ : (i) high absorbances at all concentrations of synthetic peptide, found exclusively in uninfected children or their mothers (); (ii) low signals at all PND concentrations, found in all infected neonates and in some mothers of infected neonates $(\diamond)$; and (iii) high absorbances that dropped precipitously with decreasing PND coating concentrations (a).

human serum that showed strong immunoreactivity on the antigen-limited ELISA required $5000 \mathrm{ng}$ of PND per ml (50,000-fold higher concentration) to reduce the signal (Table 4 , serum 1). These sera showed equivalent immunoreactivity on ENV9 ELISA, ruling out low immunoreactivity to PNDMN because of loss of patient humoral response (Table 4). The correlation between the antigen-limited ELISA and the competition assays showed that decreasing concentrations of PND antigen biased antibody detection to high-affinity/ avidity populations.

The significance of high-affinity/avidity antibodies was tested in pediatric HIV diagnosis. Maternal/neonatal pairs of sera were tested for reactivity with decreasing concentrations of PND-MN peptide. Patterns of reactivities with PND peptide-limited concentration in samples from infected or

Table 5. Correlation of maternal/neonatal HIV transmission to high-affinity/avidity PND antibodies

\begin{tabular}{|c|c|c|c|}
\hline \multirow{2}{*}{$\begin{array}{l}\text { Neonate } \\
\text { sample }\end{array}$} & \multicolumn{3}{|c|}{$\begin{array}{c}A(\mathrm{SD}) \text { in ELISA with } \\
\text { high-affinity/avidity } \\
\text { PND antibodies }\end{array}$} \\
\hline & $\mathrm{Ma}$ & aternal & Neonate \\
\hline \multicolumn{4}{|l|}{ Infected } \\
\hline 1 & 0.069 & $(0.01)$ & $0.074(0.008)$ \\
\hline 2 & 0.2 & $(0.005)$ & $0.174(0.006)$ \\
\hline 3 & 0.103 & $(0.0035)$ & $0.071(0.005)$ \\
\hline 4 & 0.063 & $(0.001)$ & $0.06 \quad(0.002)$ \\
\hline 5 & 0.067 & $(0.006)$ & ND \\
\hline 6 & 0.038 & $(0.001)$ & ND \\
\hline 7 & 0.09 & $(0.003)$ & ND \\
\hline 8 & 0.18 & $(0.005)$ & ND \\
\hline 9 & 0.126 & $(0.009)$ & $0.068(0.004)$ \\
\hline 10 & 0.098 & $(0.006)$ & ND \\
\hline 11 & 0.095 & $(0.01)$ & ND \\
\hline \multicolumn{4}{|l|}{ Uninfected } \\
\hline 12 & 0.71 & $(0.013)$ & $1.1 \quad(0.036)$ \\
\hline 13 & 1.2 & $(0.043)$ & $1.02 \quad(0.049)$ \\
\hline 14 & 0.2 & $(0.012)$ & $0.45 \quad(0.107)$ \\
\hline 15 & 1.27 & $(0.05)$ & ND \\
\hline
\end{tabular}

Average of three independent assays. Mean absorbance at $405 \mathrm{~nm}$ and SD generated in ELISA at coating concentrations of $0.5 \mathrm{ng} / \mathrm{ml}$ (high affinity/avidity) are indicated. Cutoff $=0.2$ was defined as the mean $A$ value of 10 seronegative samples plus five values of SD ( $P$ $<0.0001)$. ND, not determined. uninfected children are shown in Fig. 2. Three patterns of immunoreactivity were noted: $(i)$ high optimal densities at all concentrations of synthetic peptide were found exclusively in uninfected children or their mothers, (ii) low signals on all PND concentrations were found in all infected neonates and in some mothers of infected neonates, and (iii) high optical densities that dropped precipitously with decreasing PND coating concentrations were seen in 4 of 11 mothers of HIV-infected neonates; this last pattern suggested that the antigen-limitation technique was capable of discriminating a relatively weak immune response to the PND.

The antigen-limited ELISA showed that sera from all 11 mothers $(100 \%)$ of HIV-infected neonates had reactivities below the designated cutoff for the PND-MN, demonstrating the presence of only low-affinity/avidity antibodies to the PND (Table 5). Sera derived from the children (age from birth to 4 weeks) showed identical patterns. In contrast, sera from all 4 uninfected neonates demonstrated strong immunoreactivity (PND coating concentrations of $0.5 \mathrm{ng} / \mathrm{ml}$ ), suggesting that high-affinity/avidity antibodies to the PND were present. Three of the 4 paired samples from mothers of uninfected children (75\%) also had high-affinity/avidity antibodies to the PND. In mother 14 (Table 5), low-affinity/avidity antibodies to PND-MN were noted while her baby had high-affinity/ avidity antibodies.

\section{DISCUSSION}

Infection of children by HIV has increased with the increasing incidence of HIV infection in women of childbearing age. There is ample evidence of materno-fetal transmission of the disease. The factors that facilitate transmission of HIV to the fetus are still unclear. Studies implicated that low $\mathrm{T}^{+}$cell counts, maternal viremia, p24 serum antigen levels, and T-cell functions are prognostic markers for HIV vertical transmission (22-25). However, in the present prospective study, most women who transmitted HIV to their fetuses were asymptomatic, had normal $\mathrm{T}^{+}$cell counts, and had normal lymphocyte mitogenic responses to PHA, and many had no detectable p24 levels.

The role of protective maternal anti-HIV antibodies has been recently investigated. Goedert et al. (25) have suggested that lack of antibodies to gp120, as measured by Western blots, correlated to some extent with an increased risk of transmission. More recently Broliden et al. (5) reported that $31 \%$ of uninfected neonates showed immunoreactivity with gp120 amino acids 324-338 derived from the HTLV-III strain. This peptide excluded those amino acids critical for neutralization (amino acids 308-318; ref. 12). Other peptide fragments from gp120, tested in their study, including the PND region, showed lower correlations with neonate infection. Furthermore, the ELISA utilized the antigen at highantigen-coating concentrations ( $1 \mu \mathrm{g}$ per well), which did not distinguish among binding strengths of various antibody populations. Similarly, in a study of Rossi et al. (6), all of the synthetic peptides were derived from the nonrepresentative HTLV-III ${ }_{B}$ strain and were used in the ELISA at $20 \mu \mathrm{g} / \mathrm{ml}$. Such antigen-coating conditions did not distinguish among binding strengths and did not eliminate low-affinity crossreactions, which skewed the interpretation from a proper prognostic prediction, as demonstrated in Fig. 2.

Heretofore, HIV-1 immunoassays have shown poor correlation with biologically functional antibodies. A high level of cross-reaction among a variety of synthetic peptides under optimal antigen coating conditions has been reported $(15,26)$. The use of decreased PND coating concentrations eliminated these cross-reactions and detected high-affinity/avidity antibodies, as demonstrated by the PND competition assay.

This method also eliminated irrelevant cross-reactions by

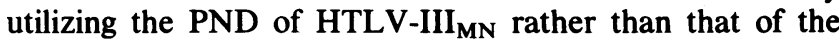


HTLV-III ${ }_{B}$ strain. The data showed that the vertical transmission of HIV was correlated with an absence of highaffinity/avidity maternal antibodies to the PND.

In one of four uninfected infants, the maternal serum consistently had a low response to PND ELISA (confirmed three times). Surprisingly, at ages 4 and 8 weeks, the baby showed a transient but measurable serum antibody titer to the gp120 PND region (data not shown). Since this child was found to be uninfected and was too young to produce his own $\mathrm{IgG}$, it is unlikely that these antibodies were actively produced by the infant. Therefore, maternal antibodies must have been transferred transplacentally. It has been observed previously that certain IgG subclasses, especially $\operatorname{IgG}_{1}$, preferentially cross the placenta and, therefore, may be detected in the newborn at higher levels than in the maternal circulation (27).

The site-directed serology described here utilized linear PND sequences and may not detect all potential HIV neutralizing domains $(18,26,28)$. Neutralization-resistant HIV strains that contain conformational variation of the PND (18, 20) would not be detected. However, our study and the studies of Broliden et al. (5) and Rossi et al. (6) support the feasibility of current subunit vaccine efforts to protect against HIV-1 infection. Levels of preexposure neutralizing antibodies in the fetus appear to abrogate the virus infection. Hence, the development of HIV vaccines and immunotherapeutics may hold promise for preventing vertical HIV transmission.

This work was supported by a grant from the National Institute of Allergy and Infectious Diseases (AI 20671), from the National Institute of Child Health and Human Development (NO1-HD-82913), and from the Diamond Foundation.

1. Falloon, J., Eddy, J., Weinere, L. \& Pizzo, P. (1989) J. Pediatr. 114, 1-30.

2. Rubinstein, A. \& Bernstein, L. (1986) Clin. Immunol. Immunopathol. 40, 115-121.

3. Blanche, S., Rouzioux, C., Guihard, M. M. L., Veber, F., Mayaux, M. J., Jacomet, C., Tricoire, J., Douaard, D., Robin, M., Courpotin, C., Cirau-Vigneron, N., LeDeist, F. \& Griscelli, C. (1989) N. Engl. J. Med. 320, 1643-1648.

4. Mok, J. Q., Giaquinto, C., De Rossi, A. \& Grosh-Warner, I. (1987) Lancet i, 1164-1168.

5. Broliden, P. A., Moschese, V., Ljunggren, K., Rosen, J., Fundaro, C., Plebani, A., Jondal, M., Rossi, P. \& Wahren, B. (1989) AIDS 9, 577-582.

6. Rossi, P., Moschese, V., Broliden, P. A., Fundaro, C., Quinti, I., Plebani, A., Giaquinto, C., Tovo, P. A., Ljunggren, K., Rosen, J., Wigzell, H., Jondal, M. \& Wahren, B. (1989) Proc. Natl. Acad. Sci. USA 86, 8055-8058.

7. Putney, S. D., Matthews, T. J., Robey, G. W., Lynn, D., Robert-Guroff, M., Mueller, T. W., Langlois, A. J., Grayeb, J., Petteway, S. R., Weinhold, K. J., Fischinger, P. J., WongStaal, F., Gallo, R. C. \& Bolognesi, D. P. (1986) Science 234, 1392-1395.

8. Matthews, T. J., Langlois, A. J., Robey, W. G., Chang, N. T.,
Gallo, R. C., Fischinger, P. J. \& Bolognesi, D. P. (1986) Proc. Natl. Acad. Sci. USA 83, 9709-9713.

9. Rusche, J. R., Lynn, D., Robert-Guroff, M., Langlois, A. J., Lyerly, K. H., Carson, H., Krohn, K., Ranki, A., Gallo, R. C., Bolognesi, D. P., Putney, S. D. \& Matthews, T. J. (1988) Proc. Natl. Acad. Sci. USA 84, 6924-6928.

10. Palker, T. J., Clark, M. E., Langlois, A. J., Matthews, T. J., Weinhold, K. J., Randall, R. R., Bolognesi, D. P. \& Haynes, B. F. (1988) Proc. Natl. Acad. Sci. USA 85, 1932-1936.

11. Rusche, J. R., Javaharian, K., McDanal, C., Petro, J., Lynn, D., Grimaila, R., Langlois, A., Gallo, R. C., Arthur, L. O., Fischinger, P. J., Bolognesi, D. P., Putney, S. D. \& Matthews, T. J. (1988) Proc. Natl. Acad. Sci. USA 85, 3198-3202.

12. Goudsmit, J., Debouck, C., Meloen, R. H., Smit, L., Bakker, M., Asher, D. M., Wolf, A. V., Gibbs, C. J. \& Gajdusek, D. C. (1988) Proc. Natl. Acad. Sci. USA 85, 4478-4482.

13. Skinner, M. A., Langlois, A. J., McDanal, C. B., McDougal, S. J., Bolognesi, D. P. \& Matthews, T. J. (1988) J. Virol. 62, 4195-4200.

14. Looney, D. J., Fisher, A. G., Putney, S. D., Rusche, J. R., Redfield, R. R., Burke, D. S., Gallo, R. C. \& Wong-Staal, F. (1988) Science 241, 357-359.

15. Devash, Y., Matthews, T. J., Drummond, J. E., Javaherian, K., Waters, D. J., Arthur, L. O., Blattmer, A. \& Rusche, J. R. (1990) AIDS Hum. Retrovir., in press.

16. Matthews, T. J., Weinhold, K. J., Lyerly, H. K., Langlois, A. J., Wigzell, H. \& Bolognesi, D. P. (1987) Proc. Natl. Acad. Sci. USA 84, 5424-5428.

17. Javaherian, K., Langlois, A. J., McDanal, C., Ross, K. L., Eckler, L. I., Jellis, C. L., Profy, A. T., Rusche, J. R., Bolognesi, D. P., Putney, S. D. \& Matthews, T. J. (1989) Proc. Natl. Acad. Sci. USA 86, 6768-6772.

18. Goudsmit, J., Kuiken, L. C. \& Nara, P. L. (1989) AIDS 3, Suppl.

19. Rubinstein, A., Sicklick, M., Gupta, A., Bernstein, L., Klein, N., Rubinstein, E., Spigland, I., Fruchter, L., Litman, N., Lee, H. \& Hollander, M. (1982) J. Am. Med. Assoc. 249, 2350-2356.

20. Abbot, M. A., Poiesz, B. J., Byrne, B. C., Kwok, S., Shinsky, J. J. \& Erlich, G. D. (1988) J. Infect. Dis. 158, 1158.

21. Centers for Disease Control (1987) Morbid. Mortal. Wkly. Rep. 36, 1-6.

22. Ryder, R. W., Nsa, W., Hassig, S. E., Behets, F., Rayfeld, M., Ekungola, B., Nelson, A. M., Mulenda, U., Francis, H., Mwandagalirwa, K., Davachi, F., Rogers, M., Nzilambi, N., Greenberg, A., Mann, J., Quinn, T. C., Piot, P. \& Curran, J. W. (1989) N. Engl. J. Med. 320, 1637-1642.

23. Italian Multicenter Study (1988) Lancet ii, 1043-1046.

24. Wiznia, A. A. \& Rubinstein, A. (1988) Ann. Nestle 46, 154-175.

25. Goedert, J. J., Mendez, H., Robert-Guroff, M., Minkoff, H., Rubinstein, A. \& Blattner, W. A. (1989) Lancet ii, 1351-1354.

26. Sun, N. C., Ho, D., Sun, C. R. Y., Liou, R. S., Gordon, W., Fung, M. S. C., Li, X. L., Ting, R., Lee, T. H., Chang, N. T. \& Chang, T. W. (1989) J. Virol. 63, 3579-3585.

27. Wilson, M. (1985) in Clinics in Immunology and Allergy: Developmental Immunology, ed. Rosen, F. S. (Saunders, London), pp. 271-286.

28. Nara, L. P. \& Goudsmit, J. (1990) Cold Spring Harbor Vaccines 90 , eds. Brown, F., Chanock, R. M., Ginsberg, H. S. \& Lerner, R. A. (Cold Spring Harbor Lab., Cold Spring Harbor, NY), pp. 297-306. 